\title{
ON THE SETTLING AND RESPONSE TIMES OF UNDERDAMPED SECOND-ORDER SYSTEMS
}

\author{
Abdul-Fattah Mohamed Ali \\ Environmental Engineering Department, College of Engineering, \\ Baghdad University, Iraq. \\ tariqjwad@yahoo.com
}

\begin{abstract}
The normalized settling time (ts $/ \tau$ ) values of oscillatory 2nd-order systems, when subjected to a step-change forcing function (SCFF), depend on the sensitivity of the measuring instrument employed to indicate the response $( \pm x \%)$. An attempt is made to mathematically relate ts $/ \tau$ to $\pm \mathrm{x} \%$ utilizing the exact, and a simplified, expression for the lower boundary of the decay envelope (LBDE). The two obtained relationships were tested against the actual ts $/ \tau$ values for a settling band range of $\pm 1 \% \leq \pm \mathrm{x} \% \leq \pm 6 \%$, covering a damping coefficient range of $0.1 \leq \zeta \leq 0.65$. Although the relationships are not exact, their general trend is a marginal overestimation of ts $/ \tau$. The relationship based on the simplified LBDE was chosen for being simpler and slightly more accurate of the two. This led to a suggested distinction between ts $/ \tau$ and the normalized response time $(\mathrm{tR} / \tau)$ with the latter assigned the value $5 / \zeta$. The ratio ts $/$ tR can thus be readily established for any $\pm \mathrm{x} \%$ value.
\end{abstract}

ABSTRAK: Masa enapan ternormal ( $\left.\mathrm{t}_{\mathrm{s}} / \tau\right)$ nilai ayunan system terbit kedua, apabila fungsi memaksa ubah berperingkat (step-change forcing function (SCFF)) dijalankan ke atasnya, bergantung kepada kepekaan alat pengukur yang digunakan untuk mengukur respons $( \pm x \%)$. Satu percubaan dijalankan secara matematik untuk mengaitkan $t_{s} / \tau$ to \pm $\mathrm{x} \%$ dengan mempergunakan ekspresi yang tepat dan mudah, pada sempadan bawah sampul reputan (lower boundary of the decay envelope (LBDE)). Dua hubungan yang diperolehi dikaji terhadap nilai $\mathrm{t}_{\mathrm{s}} / \tau$ sebenar untuk julat jalur enapan $\pm 1 \% \leq \pm \mathrm{x} \% \leq \pm 6 \%$, melingkungi julat pekali redaman $0.1 \leq \zeta \leq 0.65$. Walaupun hubungannya tidak tepat, trend umum merupakan penganggaran marginal $\mathrm{t}_{\mathrm{s}} / \tau$. Hubungan berdasarkan LBDE adalah berdasarkan LBDE yang telah dipermudahkan, ia dipilih kerana ianya senang dan agak tepat antara keduanya. Ini mendorong kepada perbezaan yang disarankan antara $\mathrm{t}_{\mathrm{S}} / \tau$ dan waktu respons ternormal $\left(\mathrm{t}_{\mathrm{R}} / \tau\right)$, dengan nilai $5 / \zeta$ yang ditetapkan kemudiannya.

KEYWORDS: process control; instrumentation; mathematical modelling; transient response; 2 nd-order system

\section{INTRODUCTION}

An underdamped second order system with $0<\zeta \leq 0.65$, when subjected to a SCFF undergoes a response which is significantly oscillatory. Under such condition, the settling time (also called the response or recovery time) is defined as the time required for the normalized response to enter the $\pm 5 \%$ band of the step change magnitude. Other definitions for $t_{\mathrm{s}}$ exist; notably, that related to the $\pm 2 \%$ band or as determined by the sensitivity of the measuring instrument [1-5]. 


\section{ESTIMATION OF SETTLING TIME}

Pollard [2] pointed out that owing to the arbitrary nature of the settling band limits (due to the specific sensitivity of the measuring instrument employed), a mathematical definition for $t_{\mathrm{s}}$ is not possible. He concluded that it can be easily measured from the response curve of a recording instrument (i.e. a posteriori). In spite of the aforementioned viewpoint, an estimate of $t_{s}$ value a priori is an advantage in many instances, e.g. in the design and analysis of control loops. The normalized response of an underdamped $2^{\text {nd }}-$ order system to a SCFF of magnitude A is,

$$
\frac{\mathrm{Y}(\mathrm{t})}{\mathrm{AK}}=1-\frac{1}{\sqrt{1-\zeta^{2}}} \mathrm{e}^{-\frac{\zeta}{\tau} \mathrm{t}} \sin \left(\frac{\sqrt{1-\zeta^{2}}}{\tau} \mathrm{t}+\tan ^{-1} \frac{\sqrt{1-\zeta^{2}}}{\zeta}\right)
$$

For a $\pm \mathrm{x} \%$ settling band, its limits would correspond to $\mathrm{Y}(\mathrm{t}) / \mathrm{AK}$ values of $(1+0.01 \mathrm{x})$ and $(1-0.01 \mathrm{x})$ respectively. This renders the value of the second term of Eq. (1) equal to $0.01 \mathrm{x}$ in absolute value. Therefore, $\mathrm{t}_{\mathrm{s}} / \tau$ is the shortest normalized time which satisfies this condition; provided that the second term will not exceed $10.01 \mathrm{xl}$ for $\mathrm{t} / \tau>\mathrm{t}_{\mathrm{s}} / \tau$.

The exact expression for the lower boundary of the decay envelope (LBDE) related to the normalized response represented by Eq.(1) is $\left(1-\frac{1}{\sqrt{1-\zeta^{2}}} \mathrm{e}^{-\frac{\zeta}{\tau}}\right.$ ) (Ogata [5]). Pollard [2], however, gave it as $\left(1-\mathrm{e}^{-\frac{\zeta}{\tau} \mathrm{t}}\right)$; neglecting $\zeta^{2}$ which is justifiable for small values of $\zeta$. Pollard further pointed out that $\left(1-\mathrm{e}^{-\frac{\zeta}{\tau} \mathrm{t}}\right)$ is the normalized response of a $1^{\text {st }}$-order system, whose time constant is $\tau / \zeta$, to a SCFF.

These two expressions for the LBDE were utilized to obtain the following equations for the estimation of $t_{s} / \tau$ as related to $a-x \%$ settling band limit. Hence,

$$
\frac{t_{s}}{\tau}=\frac{-\ln (0.01 \mathrm{x})}{\zeta}
$$

Corresponding to $\left(1-\mathrm{e}^{-\frac{\zeta}{\tau} \mathrm{t}}\right) \mathrm{LBDE}$, and

$$
\frac{t_{s}}{\tau}=\frac{-\ln (0.01 x)}{\zeta}-\frac{1}{2 \zeta} \ln \left(1-\zeta^{2}\right)
$$

Corresponding to $\left(1-\frac{1}{\sqrt{1-\zeta^{2}}} \mathrm{e}^{-\frac{\zeta}{\tau} \mathrm{t}}\right)$ LBDE.

Eq.'s (2) and (3) were tested against the actual $t_{s} / \tau$ values for settling bands ranging from $\pm 1 \%$ to $\pm 6 \%$ over the range $0.1 \leq \zeta \leq 0.65$. The results are shown in Fig.'s (1) to (6). The two equations generally overestimate $t_{s} / \tau$ but give reasonably close values to the actual ones. Their respective values of $t_{s} / \tau$ were too close to be distinguishable on the same graph; which necessitated the use of separate plots for each $\pm x \%$ value.

The percentage error as defined by;

$$
\% \text { error }=\frac{\left(t_{s} / \tau\right)_{\text {calc. }}-\left(t_{s} / \tau\right)_{\text {act. }}}{\left(t_{s} / \tau\right)_{\text {act. }}} \times 100
$$


ranged from $-8.35 \%$ to $26.86 \%$ with an average of $6.93 \%$ for Eq.(2) and from $0.00 \%$ to $31.62 \%$ with an average of $10.00 \%$ for Eq.(3) over the whole range tested. Therefore, it may be concluded that Eq.(2) is the better one for being simpler and marginally more accurate.

For settling bands of $\pm 2 \%$ and $\pm 5 \%$, Eq. (2) gives $t_{s} / \tau=3.912 / \zeta$ and $t_{s} / \tau=2.996 / \zeta$ respectively. These two results correspond to the familiar expressions of $t_{s} / \tau=4 / \zeta$ for $\pm 2 \%$ settling band and $t_{s} / \tau=3 / \zeta$ for $\pm 5 \%$ settling band mentioned in textbooks as approximate relationships (e.g. Ogata [5]); further validating the approach presented here.
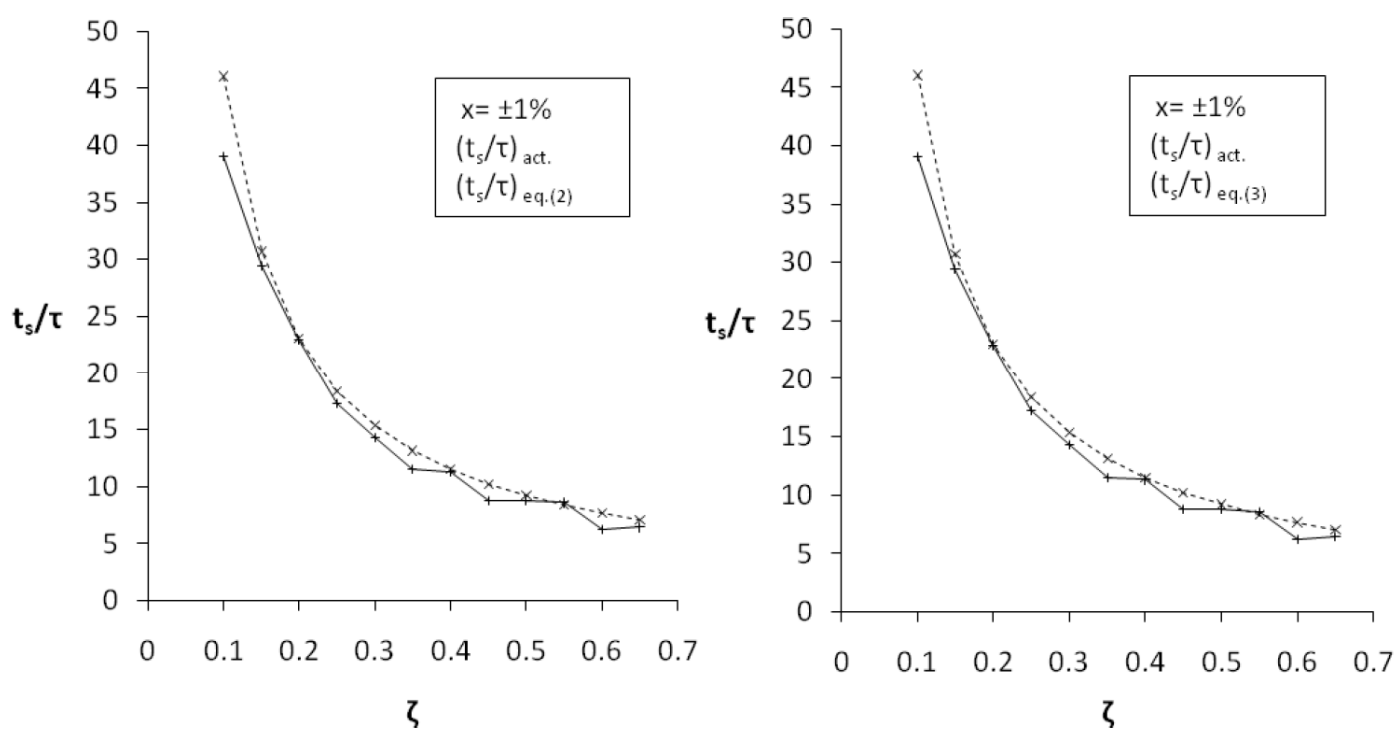

Fig. 1: Actual and calculated $\left(\mathrm{t}_{\mathrm{s}} / \tau\right)$ vs. $\zeta$ for $\pm 1 \%$ settling band.
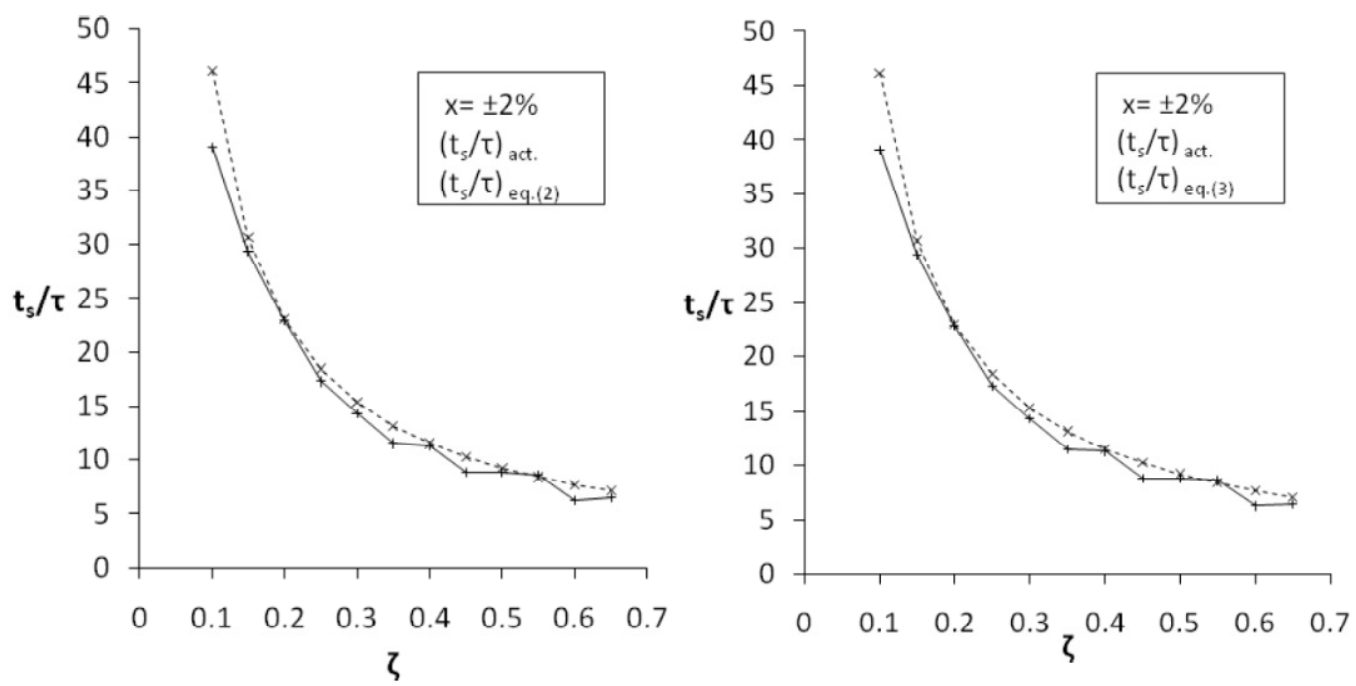

Fig. 2: Actual and calculated $\left(\mathrm{t}_{\mathrm{s}} / \tau\right)$ vs. $\zeta$ for $\pm 2 \%$ settling band. 
IIUM Engineering Journal, Vol. 12, No. 5, 2011: Special Issue -1 on Science and Ethics in Engineering Mohamed Ali
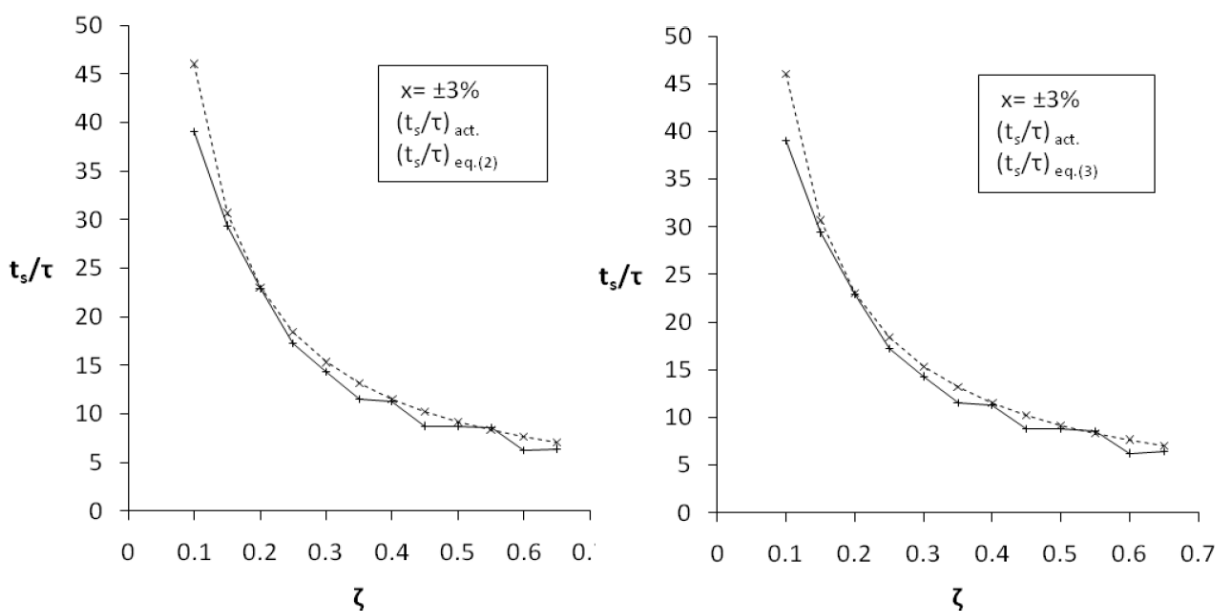

Fig. 3: Actual and calculated $\left(\mathrm{t}_{\mathrm{s}} / \tau\right)$ vs. $\zeta$ for $\pm 3 \%$ settling band.
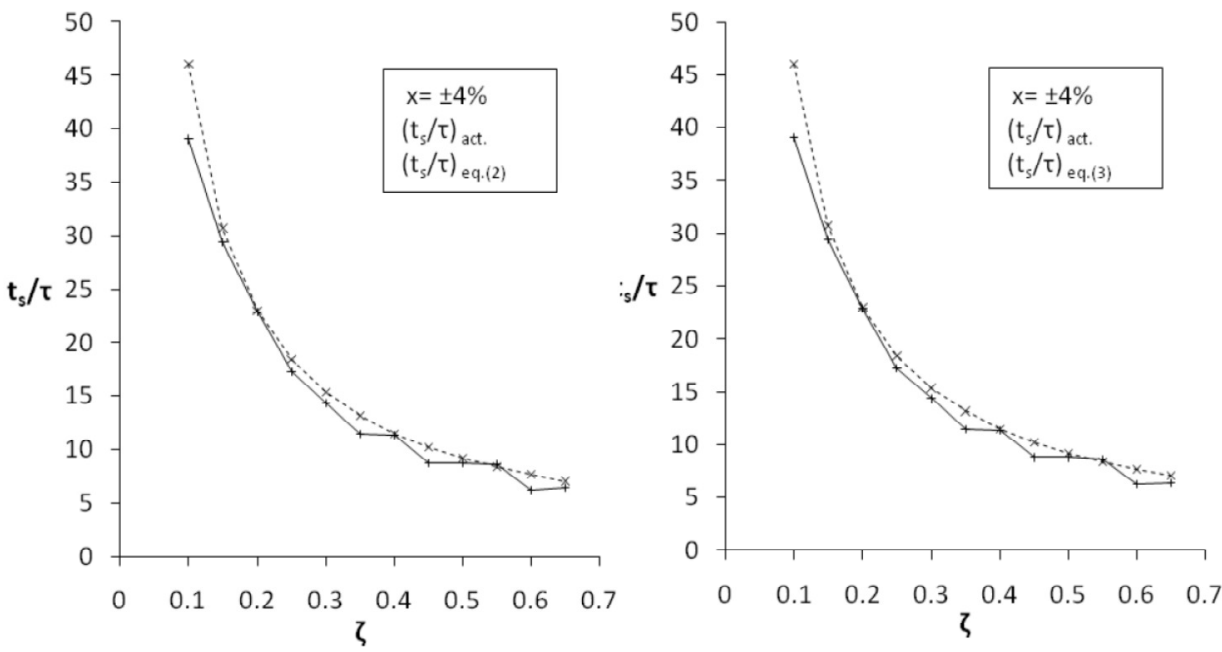

Fig. 4: Actual and calculated $\left(\mathrm{t}_{\mathrm{s}} / \tau\right)$ vs. $\zeta$ for $\pm 4 \%$ settling band.
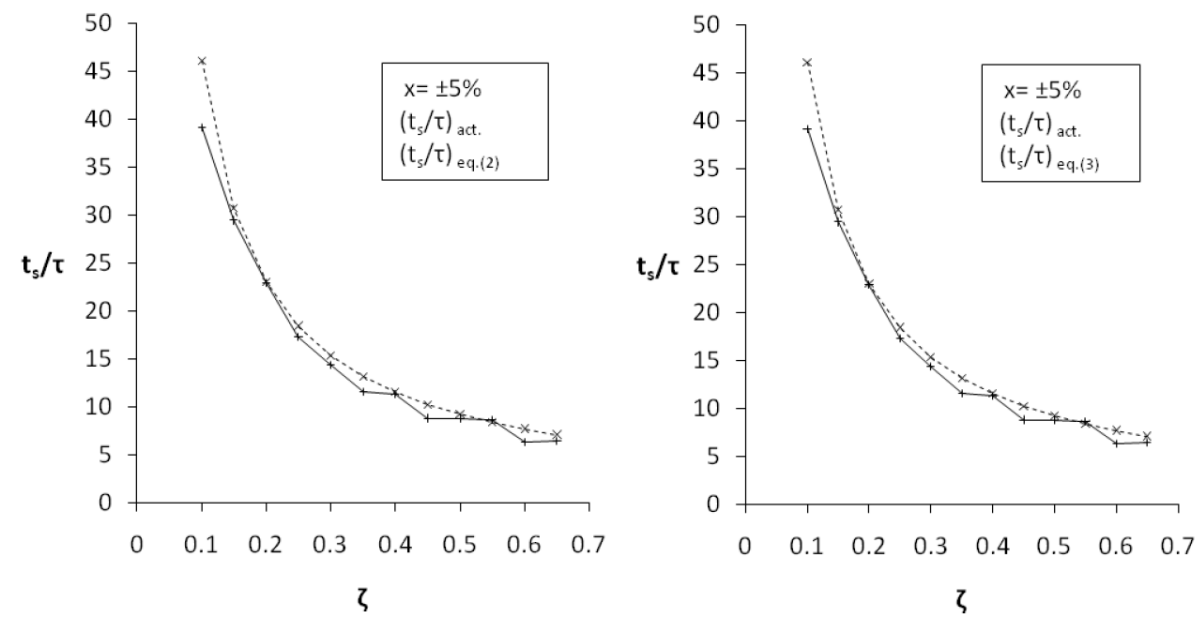

Fig. 5: Actual and calculated $\left(\mathrm{t}_{\mathrm{s}} / \tau\right)$ vs. $\zeta$ for $\pm 5 \%$ settling band. 
IIUM Engineering Journal, Vol. 12, No. 5, 2011: Special Issue -1 on Science and Ethics in Engineering Mohamed Ali
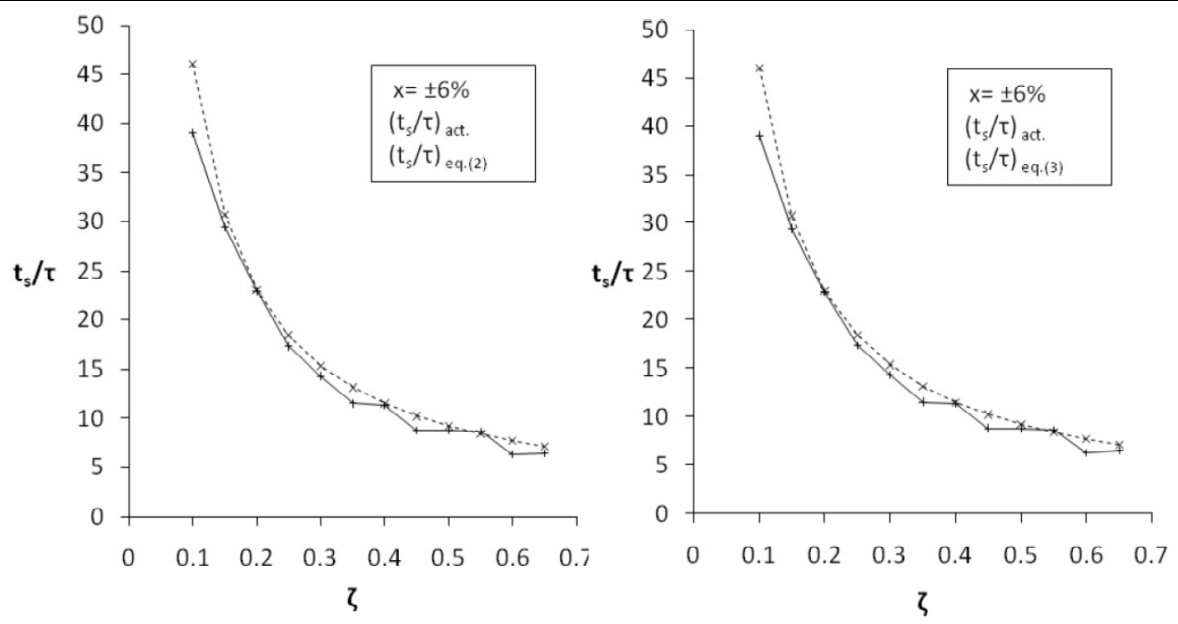

Fig. 6: Actual and calculated $\left(\mathrm{t}_{\mathrm{s}} / \tau\right)$ vs. $\zeta$ for $\pm 6 \%$ settling band.

\section{SETTLING TIME VS. RESPONSE TIME}

As a consequence of the adoption of Eq.(1), the following argument is presented as a basis for suggesting that a distinction should be made between $t_{s}$ and the response time $\left(t_{R}\right)$.

For a $1^{\text {st }}$-order system subjected to a SCFF, the response time may be defined as that at which the normalized response exceeds $99 \%$ of the step change magnitude. Hence, a time interval equal to five times the system's time constant, corresponding to $99.3 \%$ of the step change magnitude, would serve this purpose. If this criterion is adopted, then by referring back to Pollard's [2] expression for the LBDE, i.e. $\left(1-\mathrm{e}^{-\frac{\zeta_{t}}{\tau}}\right)$, the normalized response time for an underdamped $2^{\text {nd }}$-order system would accordingly be $5 / \zeta$. In other words, $\mathrm{t}_{\mathrm{R}} / \tau$ would be the normalized settling time for a \pm $0.7 \%$ settling band according to Eq.(2), i.e.

$$
\frac{t_{R}}{\tau}=\frac{-\ln (0.007)}{\zeta}=\frac{4.962}{\zeta} \text { or } \frac{5.0}{\zeta}
$$

Hence, for $\mathrm{a} \pm \mathrm{x} \%$ band limits $\mathrm{t}_{\mathrm{s}} / \mathrm{t}_{\mathrm{R}}$ would be,

$$
\frac{t_{s}}{t_{R}}=\frac{-\ln (0.01 x)}{5}
$$

Table (1) gives rounded-off values of $t_{s} / \tau$, based on Eq.(2), and $t_{s} / t_{R}$, based on Eq.(6), for the range $0.7 \% \leq \pm \mathrm{x} \leq 6 \%$ for comparison purposes.

\section{CONCLUSION}

A simple mathematical formula is presented to estimate a priori the normalized settling time values of oscillatory $2^{\text {nd }}$-order systems, when subjected to a SCFF, for any value of the measuring instrument sensitivity. A distinction is made between normalized settling and response times of such systems, with the latter assigned the value of $5 / \zeta$. Accordingly, ratios of settling to response times can readily be established. 
IIUM Engineering Journal, Vol. 12, No. 5, 2011: Special Issue -1 on Science and Ethics in Engineering Mohamed Ali

Table $1: \mathrm{t}_{\mathrm{S}} / \tau$ and $\mathrm{t}_{\mathrm{s}} / \mathrm{t}_{\mathrm{R}}$ values for $0.7 \% \leq \pm \mathrm{x} \leq 6 \%$

\begin{tabular}{ccc}
\hline$\pm \mathrm{x} \%$ & $\zeta\left(\mathrm{t}_{\mathrm{s}} / \tau\right)$ & $\mathrm{t}_{\mathrm{s}} / \mathrm{t}_{\mathrm{R}}$ \\
\hline 0.7 & 5.00 & 1.00 \\
1.0 & 4.60 & 0.92 \\
1.5 & 4.20 & 0.84 \\
2.0 & 4.00 & 0.78 \\
2.5 & 3.70 & 0.74 \\
3.0 & 3.50 & 0.70 \\
3.5 & 3.35 & 0.67 \\
4.0 & 3.22 & 0.64 \\
4.5 & 3.10 & 0.62 \\
5.0 & 3.00 & 0.60 \\
5.5 & 2.90 & 0.58 \\
6.0 & 2.81 & 0.56 \\
\hline
\end{tabular}

\section{REFERENCES}

[1] D.R. Coughanowr, and L.B. Koppel, "Process Systems Analysis and Control", McGraw-Hill Kogakusha, Tokyo, pp. 85-88, 1965.

[2] A. Pollard, " Process Control", $2^{\text {nd }}$ Reprint, Heinemann Educational Books, London, pp. 75-78, 83, 1981.

[3] G. Stephanopoulos, "Chemical Process Control", Prentice-Hall, Englewood Cliffs, New Jersey, pp. 190-191, 1984.

[4] D.E. Seborg, T.F. Edgar, and D.A. Mellichamp, "Process Dynamics and Control", John Wiley (Asia), Singapore, pp. 117-118, 2004.

[5] K. Ogata, “ Modern Control Engineering “, $5^{\text {th }}$ Edition, Pearson, Upper Saddle River, New Jersey, p. 180-183, 2010.

\section{Notation}

A SCFF magnitude

$\mathrm{K} \quad$ Steady state gain

$t_{R} \quad$ Response time

$\mathrm{t}_{\mathrm{s}} \quad$ Settling time

$\pm x \%$ Sensitivity of measuring instrument, corresponding to settling band limits

$\mathrm{Y}(\mathrm{t}) \quad$ System's transient response

\section{Greek}

$\zeta \quad$ Damping coefficient

$\tau \quad$ Characteristic time

\section{Abbreviation}

act. actual

calc. calculated

eq. equation

LBDE Lower boundary of the decay envelope

SCFF Step change forcing function 